\title{
Truth in the Time of Infowars: Moral Politics and Conscience
}

\author{
Kacper Szulecki \\ kacper.szulecki@stv.uio.no \\ Department of Political Science \\ University of Oslo \\ Eilert Sundts hus \\ Moltke Moes vei 31 \\ 0851 Oslo, Norway
}

\begin{abstract}
Speaking truth to powers-that-be and overthrowing a "regime of lies" were both dissident trademarks during the Cold War era. But what if overreliance on such an idealized and static notion of Truth can be a problem in an age of post-factual politics and information warfare? In this essay, I first problematize the idea that "truth will set us free" and re-read Vaclav Havel's The Power of the Powerless together with a contemporary work- the film Camouflage by Krzysztof Zanussi - to find other foundations for political strategies, beyond the "struggle for truth," that might transcend the post-totalitarian situation and inform our normative choices and political agency today. In a reality over-flooded with information, where spreading doubt and forging counter-narratives has become a weapon, and where conspiracy theories seem to gain ground, relying on a self-evident distinction between Truth and Lies no longer has the power for political mobilization. It is individual conscience-nesting moral and political responsibility within the individual-rather than an externally existing Truth that might prove a more productive compass in a world of multiple vantage points and continuous re-interpretations.
\end{abstract}

Then you will know the truth, and the truth will set you free.

If I speak the truth, why do you not believe Me?

John, 8:32 and 46

Among the axioms on which Vaclav Havel's moral political strategy rests, one stands out most visibly: the simple belief that truth will win and will set us free. "Living in truth," that dissident ideal of personal liberation, was to bear important political implications. While simple and pure in its moral clarity, it now seems to have been the dissidents' greatest folly. George Lakoff traces the idea that truth brings about political legitimacy back to the Enlightenment and its emphasis on the power of reason. ${ }^{1}$ Analyzing the roots of Democrats' humiliating electoral defeats in 2000-2004, Lakoff suggests that the fallacious belief in the power of truth - the notion 
that lies and manipulation can be countered by the sheer force of facts-misses the point of politics. People, says Lakoff, do not think and do not vote for truth or reason, they vote identity and follow passion.

This is a bitter truth about politics, albeit hard to accept - especially in Central Europe. The Czechs notably tend to build their idealized self-image on the attachment to the motto "Truth prevails!" (veritas vincit in Latin and pravda vitězí in Czech), which was historically something between a credo and a war cry. ${ }^{2}$ Havel romantically follows the myth of Jan Hus and makes Truth central to his concept of moral political action. From today's perspective, this seems to turn out to be a mistake.

The modern world is very complex. This is not to say that it was ever simple or easily understandable, but the "noise" and chaos of information, global dynamics, and the political flux of today can give a headache to the most intellectually adept. This arguably new condition makes Havel's Power of the Powerless at the same time painfully outdated and very insightful.

Havel's 1978 analysis of the post-totalitarian system pointed out its key features. One was the hegemonic (internalized, banal and almost invisible) function of ideology. Communist ideology was, by the late 1970s, hollowed out, yet it performed a stabilizing and normalizing function in that peculiar system. ${ }^{3}$ It was, according to Havel, an asylum and an alibi-an alibi for not-thinking, not-acting, not-caring, and not-asking for the Truth. "Living a lie" was to be the result of a more general, existentially and politically understood human condition-coupled with hollow, ritualized ideology.

The response to that, "living in truth," was for Havel a morally grounded political strategy. In a minimal sense, it could merely be a passive form of resistance. All it required was renunciation - a refusal to participate in the industry of lies. This simple moral act of being true to oneself acquired a political dimension automatically. Truth was a factor of power in itself. It was supposed to have a liberating potential of its own. Havel also talks about more active dissident postures. These focused on building and strengthening "civil society" as a structure parallel to the state - a "parallel polity," to borrow Václav Benda's term. ${ }^{4}$

While the historical analysis cannot be contested, the value of Havel's advice does not seem that powerful in Central Europe today. Authoritarianism, with its monopolist claim on access to and circulation of information, greatly inflates the value of Truth as a political and moral currency. Difficult to obtain, monopolized and blocked by the regime, truth in the "factual" sense becomes a goal in itself, not just a means of quality political and social life. In a democracy individual moral dissent no longer has that political power; to live a "full life" requires activity. However, Havel's recipe for positive action-building structures alternative to the mainstream - if taken literally also seems to be a dead-end street. Civil society should be at the heart of the political sphere, and not, as Havel proposed, on its margins, playing the role of an external challenger of state power. ${ }^{5}$

Paradoxically, the passages of Havel's essay that seemed less important at the time of writing help us bridge the gap between 1978 and today. Crucially, he notes that despite all their peculiarity, at a deeper level post-totalitarian states were ultimately a form of consumerist 
society. This means that the existential condition of a "crisis of identity," a "crisis of the modern technological civilization as a whole," and a context-specific moral crisis of society can be seen as symptoms of something much larger than "life under Communism." That crisis was defeated neither by the transition from mono-party authoritarianism to parliamentary democracy nor by the shift from planned economies to capitalism. It remained unaddressed, not worked though, and in some ways aggravated by the rapidity of societal change after 1989.

That universal diagnosis of the late modern condition is something uncommon within the Central European dissident and intellectual tradition, which has proudly tended to claim the moral high ground in relations with Western counterparts. That moral superiority has been held to arise from Central Europe's unique historical experience of two totalitarianisms. Havel himself, in his brilliant "Anatomy of a Reticence" (1985), sneered at naive Western peace activists, who seemed lost in a situation that was perfectly clear and to raise questions where answers seemed already given. ${ }^{6}$ Their most important sin in the eyes of dissidents east of the Iron Curtain was that they continuously and relentlessly tried to draw parallels between their free countries and East European authoritarianism, between their struggle and the risky, tiresome, and morally superior cause of the real dissidents. Such parallels, even modest ones, were perceived as offensive - after all, the conditions were morally incomparable. ${ }^{7}$

At a conference in 2011, commemorating the Polish "Freedom and Peace" (WiP) movement, I witnessed a scene that constitutes a great epilogue to the East-West rows of the 1980s. ${ }^{8}$ One participant was complaining about state surveillance; the poor quality of democratic institutions, which serve business interests rather than the people; police abuses; and the crawling hegemony of the dominant, consumerist ideology. Another put this angst in some perspective, talking about his own country, where only some days earlier riot police had brutally attacked a peaceful demonstration, he had been badly beaten, and no media coverage had been allowed. The first of the speakers was not a British END (European Nuclear Disarmament) activist; he was a Pole, a prominent member of the WiP movement who had remained an activist. The latter was an actual dissident from Belarus. ${ }^{9}$

What we can learn from this scene as well as the earlier East-West dialogue is that civil society activism and a "dissident posture" in conditions of authoritarianism and democracy do encounter different challenges, but also share some features. Neither accusations of naiveté nor moralizing can help us in understanding these.

This brings us to the issue of tension between Lies and Truth, as well as conformity and non-conformity, which is central to The Power of the Powerless. Some insights can be drawn from the work and thoughts of Havel's fellow artist and contemporary (only three years younger), the Polish film director Krzysztof Zanussi. As Charter 77 emerged, Zanussi had screened one of his most famous and important films: Camouflage (1977). It is the story of a young, idealistic academic, Jarosław, confronted at his university institute by mechanisms of power and social relations that he refuses to accept. His dialogues with a self-consciously cynical older colleague, Docent Szelestowski, have become an icon of the "cinema of moral anxiety" - a 
powerful and symptomatic element of Polish culture in the 1970s and 1980s, intimately tied to the late socialist experience.

The moral decay and cynicism that are the film's subject are completely de-politicized; no reference to the regime is made or necessary. Although in the late 1970s the movie was seen as an allegory of post-totalitarian social relations (in many ways it resembles the brief story of the brewmaster $\breve{S}$. in Havel's essay), it remains a sadly true picture of the Polish higher education system (and not only that) today. Thus, it illustrates well Havel's universalizing claims on the existential level, and a more general story of conformity in late modern society, by no means unique to Communist regimes.

If we accept that certain features of our Central European states and societies have changed dramatically in the past four decades, while some broader and deeper elements have remained constant, we can compare "dissident" strategies in those two contexts and ask whether "living in truth" was and remains a fruitful strategy for moral political action.

We have already noted that in democracies Truth does not have the political power that it concentrates in authoritarian regimes. A more fundamental problem, however, is the fuzziness and plurality of truths. While post-totalitarian ideology created a tension through the widening gap between its ritual and the real human condition, it also set the restriction of information at the forefront of state activity, making simple Facts an important subversive device.

The contemporary world is characterized by democratization of communication and an unprecedented pluralism of broadcasting channels. Everyone can now write and potentially be read, make videos and potentially be watched. Zanussi once remarked that when he was young, things were simple: if it was printed, it was true. Late socialism reversed that statement for many people, at least as far as official publications were concerned: if it was in Rudé právo or Trybuna $L u d u$, it was lies. The first signals of increasing complexity appeared already at that time, though, with samizdat breaking the official monopoly for disseminating information and opinion. If all official publications were lying, people looked to samizdat for truth. Marek Nowakowski's 1982 short story, aptly entitled "Hunger for Truth," tells of a man discovering a samizdat booklet that described a Jewish plot behind dissent:

I am no racist, oh no! But different things happen in life.... [It was after all] published in the underground.... The government had nothing to do with it [...] I am merely a regular bread eater. How can I orient myself in this thicket? What is right and what is not right? Where is the truth and where the falseness? With what lantern should I illuminate this darkness? ${ }^{10}$

Today the internet plays the role of samizdat as a tool of "self-publishing" and possibly uncovering both hidden truths and imagined plots. When facts are abundant - and we are flooded by information and facts that we cannot digest - attention moves to interpretation. We are overwhelmed, and one can probably say that flooding the world with truths, perspectives, opinions, and vantage points becomes a strategy of governing — or maybe an agentless governmentality, to use Michel Foucault's popular term. ${ }^{11}$

Nowhere has this relativization and destabilization of Truth, merging fact with opinion, information with interpretation, and the instrumental political use of that practice become so clear in recent years as in the way Russia uses diverse media and information channels for its 
purposes in the aftermath of the 2014 Ukraine crisis. Peter Pomeranzev and Michael Weiss claim that Russia has weaponized information, turning media into an arm of state power projection. ${ }^{12}$ This seems to be the difference and ingenuity of Moscow's "information warfare," as opposed to Soviet propaganda, claim Edward Lucas and Ben Nimmo. ${ }^{13}$ While old propaganda was merely about crudely promoting the Kremlin's agenda, the new "information warfare" is "calibrated to confuse, befuddle, and distract." This is nicely summarized in the motto of the multilingual television channel RT (formerly Russia Today): "question more." That quip arguably takes the Enlightenment ideal of a critical and sharp reason beyond the frontier of relativism and into nihilism, aiming at provoking doubt and amplifying disagreement.

In October 2015, Zanussi was interviewed by the RT reporter Oksana Boyko in the program entitled "Fact or F(r)iction?" (sic). What was perhaps intended as an interesting insider's critique of Poland and the European Union from a director recognized and popular in Russia turned into a heated debate about the meaning of objectivity, the frontiers of propaganda, and the means of searching for Truth. Zanussi-a physicist by training - noted that while absolute objectivity is beyond our reach, there is always a criterion of Truth. The fact that we may have, and increasingly see, contradicting narratives and interpretations does not mean that we have contradictory Truths. While Boyko consistently attempted to relativize the meaning of "objectivity" and "propaganda," Zanussi kept a firm line, defining propaganda as an intended distortion of truth to move feelings and promote a vision that is not objective, pointing to hidden interests behind different statements. "It is - however-not propaganda to promote Truth." Boyko pressed: "But who is the judge? Who can say where the truth is? Is it the majority?" "Certainly not!" replied Zanussi. "It is our conscience."

Tomáš Garrigue Masaryk believed that "political praxis has to be moral."14 Havel, who as president liked to be compared to Masaryk and to see himself as Masaryk's intellectual heir, interpreted this general call as avoiding one's involvement with lies. In conditions where Truth became much less obvious and much less politically powerful, the dissident posture built around it often became a source of frustration for activists and of aversion for their environment. In Zanussi's film, Szelestowski famously calls the principled Jakub a "world-mender" and claims that his moralizing outlook leads to "the Inquisition, if not the Gestapo." Though the accusation is ridiculous, Jakub is powerless in his attempts at defending his view. Note that Szelestowski's words - accusing the "truth lover" of moralizing, imposing, and lecturing from a self-proclaimed moral higher ground - sound like a very familiar critique of dissent across Central Europe by both Communist apparatchiks and the "silent majority" asking to be left alone in the difficult task of accommodation to late socialism.

Truth is no less valuable, but because of today's grey reality - very far from the blackand-white vision of The Power of the Powerless, where Truth and Lies were clearly distinguishable - it seems to be a faulty point of departure. Ideology is no longer the alibi nor is it the enemy, making distinctions clear. It is merely one among many principles.

But Masaryk's call can be read differently: as one that puts an internalized value system, and thus a conscience, at the heart of moral politics. In his 1983 series of lectures entitled 
"Fearless Speech," Foucault tried to reconstruct and reinstall the ancient Greek concept of parrhesia. In short, parrhesia means speaking truth to power, no matter what the cost. The act of confronting the "powers that be" with truth is a test for the rulers as much as an act of courage for the parrhesiastes. "A sovereign shows himself to be a tyrant-says Foucault-if he disregards his honest advisors, or punishes them for what they have said." ${ }^{15}$ This applies to our democratic systems, too. But Foucault warns that parrhesia can also take a dangerous form: without a feeling of responsibility it may turn into populism, although Foucault does not use that word. Parrhesia can become provocative just for the sake of scandalizing and provoking (as in the case of the young student Konrad in Camouflage, whose rebellion turns from principled parrhesia to violence and hysteria). Truth requires responsibility, and that again links it back to individual conscience.

Zanussi consistently proposes conscience as the central concept-and that is also the suggestion made in Camouflage. It is our only guide in ambivalent, grey situations. While truth is external, conscience is nested in the individual and anchored in values, and the ultimate (according to Zanussi, universal) distinction between right and wrong. It is thus not merely about sheer facts, true or false, but facts combined with an interpretation held against some ideal that our conscience can evaluate as right or not.

Although Szelestowski, the devil's advocate, suggests that conscience is merely a product of encoded, internalized values received through socialization and that, luckily, our selfawareness allows us to modify it, to liberate ourselves from the web of imperatives and taboos to "survive in this world," it is clear that this comes at a psychological cost-and thus leaves conscience as the only stable element. This is not to say that everyone's conscience is always a clear guide. Zanussi compares moments of upheaval and change-like revolutions or transformation - to "a magnetic tempest," skewing the "compass in our hearts."

Living in truth does not seem to be an act of courage today. Facts are accessible, and the moral and political impact of that posture is limited. This does not mean that Truth is less of a value or that we should not strive to get as close to it as possible. It is now, however, less of a moral act of resisting lies and more of an active quest in which a critical approach is necessary. Conscience is closely linked to that critique, while no truth can ever be taken at face value.

The centrality of conscience brings values to the scene and gives them a universal anchor that is not easily moved. This implies being above interest, and above ideology, which can come at a cost even for established figures in stable democracies - as the life stories of Raymond Aron and Albert Camus attest. Conscience is not only what makes it possible to evaluate where Truth is, but also the driver for seeking it.

But conscience, if Zanussi is right, must be nurtured - and this resonates with Havel's positive, if utopian, program for societal improvement. In his "post-democratic" vision, openly indebted to Masaryk, he notes that the only way to defeat civilizational and moral crisis is through grassroots, organic work to overcome decay-with education in humanitarian values at the core. The post-democratic dissident program has thus to be cast around this idea. So far, over a quarter of a century after the Velvet Revolution, the situation looks bleak. The rise of 
particularism, nationalism, and xenophobia across the region-very remote from humanist ideas - made the publicist Jakub Patočka note the grand failure of civic education. ${ }^{16}$ We are surrounded by "an uneducated society," and in Poland one can now often hear former dissidents and liberal intellectuals bitterly note that "we have lost education, lost a whole generation." In hindsight we see that Havel's Power of the Powerless was also a warning against that deeper crisis. We just happened to look the other way.

${ }^{1}$ George Lakoff, Don't Think of an Elephant! (White River Junction, VT: Chelsea Green, 2004).

${ }^{2}$ For an anthropological discussion of the Hussite legacy see Ladislav Holy, The Little Czech and the Great Czech Nation: National Identity and the Post-Communist Transformation of Society (Cambridge: Cambridge University

Press, 1996). These traditions — or rather their creative use in political struggles — had an impact on the "localization" of human rights and other discourses by the dissidents in the 1970s and 1980s. See Kacper Szulecki, “Hijacked Ideas: Human Rights, Peace, and Environmentalism in Czechoslovak and Polish Dissident Discourses," East European Politics and Societies 25, no. 2 (2011): 272-95.

${ }^{3}$ Elsewhere I discuss the post-totalitarian system as one characterized by "institutionalized disorder," which is linked to the relationships among ideology, the letter of the law, and political practice. See Kacper Szulecki, “Order of the Orderless: Dissident Identity between De-Stabilization and Re-Stabilization," in Rethinking Order: Idioms of Stability and De-stabilization, edited by Nicole Falkenhayner, Andreas Langenohl, Johannes Scheu, Doris

Schweitzer, and Kacper Szulecki (Bielefeld: Transcript Verlag, 2015), 105-124.

${ }^{4}$ Václav Benda, “The Parallel 'Polis'," in Civic Freedom in Central Europe: Voices from Czechoslovakia, edited by H. Gordon Skilling and Paul Wilson (Houndsmills, UK: Macmillan, 1991).

${ }^{5}$ This seems closer to Jacek Kuron's political strategy of "setting up committees rather than setting them on fire."

${ }^{6}$ Václav Havel, “Anatomy of Reticence,” translated by Erazim Kohák, in Open Letters: Selected Prose, 1965-1990, edited by Paul Wilson (London: Faber and Faber, 1991), 291-322.

${ }^{7}$ Timothy Garton Ash, The Polish Revolution: Solidarity (London: Jonathan Cape, 1983), 332-37.

${ }^{8}$ For more on the difficulties of East-West dialogue on peace see Kacper Szulecki, "'Freedom and Peace Are Indivisible': On the Czechoslovak and Polish Dissident Input to the European Peace Movement, 1985-89," in Entangled Protest: Transnational Perspectives on the History of Dissent in Eastern Europe and the Soviet Union, edited by Robert Brier (Osnabrück: Fibre, 2013), 199-229; and Szulecki, "Heretical Geopolitics of Central Europe: Dissidents, Intellectuals and an Alternative European Order,” Geoforum, no. 65 (2015): 25-36. 
${ }^{9}$ Mariusz Maszkiewicz and Dariusz Zalewski, eds., Ruch Wolność i Pokój w relacjach międzynarodowych (19851990): Materiały z konferencji pt. „Bezpieczeństwo i Tożsamośc”” (Warszawa, 7-8 października 2011). (Warsaw: Akademia Ponad Granicami, 2012).

${ }^{10}$ Marek Nowakowski, Raport o stanie wojennym (Białystok: Zakłady Wydawnicze Versus, 1990), 69.

${ }^{11}$ Michel Foucault, Sécurité, territoire, population: Cours au Collège de France (1977-1978) (Paris: Éditions du Seuil, 2004).

${ }^{12}$ Peter Pomerantsev and Michael Weiss, "The Menace of Unreality: How the Kremlin Weaponizes Information, Culture and Money," Interpreter, 22 November 2014.

${ }^{13}$ Edward Lucas and Benjamin Nimmo, "Information Warfare: What Is It and How to Win It?" CEPA Infowar Paper no. 1, 2015.

${ }^{14}$ Karel Čapek, "Politická teorie a praxe," in Hovory s T. G. Masarykem (Prague: Masarykův ústav a Archiv AV ČR, 2013 [1931]).

${ }^{15}$ Michel Foucault, Fearless Speech (Los Angeles: Semiotext(e), 2001), 23

${ }^{16}$ Jakub Patočka, “Nevzdělaná společnost,” Deník Referendum, 1 September 2015. 